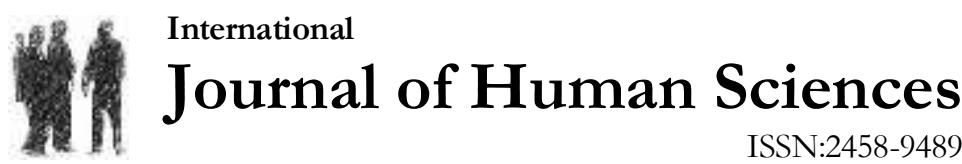

Volume 14 Issue 3 Year: 2017

\section{Children and nutrition}

\author{
Evren Ebru Altınci ${ }^{1}$
}

\begin{abstract}
It is possible to raise healthy generations by improving the awareness levels of the role models (parents, teachers etc.) who will shape the perspectives of future parents towards nutrition and physical activity. That children receive adequate levels of nutrition from proper sources, which is vital for children's growth and development, is considerably under the control of external factors (e.g. family and friends' eating habits, third person's care/knowledge and experiences such as teachers/trainers etc.). Considering nutrition and the intense physical activity of preschoolers, which is an inherent characteristic of that development stage, and especially the children who are guided to do more intense physical activity, the case becomes more complex. Thus, with the aim to address children's energy depletion from intense physical activity, it is suggested to provide children with attractive alternatives. Including some of these alternatives, this study aims to reveal the significance of an adequate and balanced diet as well as proper planning of physical activity and periodic assessments at the appropriate time and conditions so that the children who start regular physical activity display optimal performance.
\end{abstract}

Keywords: Children, Nutrition, Physical Activity

\section{Introduction}

Children should gain habits of proper diet and physical activity so that they become healthy adults in the future. Responsibilities which are appropriate for their age should be given to children such as including physically active home games during leisure time activities, encouraging them to participate in after-school activities and organizing housework/dining times etc. Considering the fact that childhood habits maintain throughout their lives, it should not be ignored that the shopping and cooking habits of children will be parallel with their families' habits when they grow up. That preschool education is not limited to in-class activities, but includes physical activities is only possible with preschool teachers' willingness and resolution to integrate more activities which support children's basic movement abilities in the curriculum. We see that the majority of internationally successful athletes began their training when they were children. The path to a healthy generation follows increasing the awareness levels of the 'role models' of children (e.g. parents, teachers etc.) who are parents of future generations, about diet and physical activity. For the sake of embodying the various small and large scale contributions which have been made in educational and health policies in Turkey for children, we still need more scientific studies which will be conducted at the national level. Free postnatal support for parents (although it is not limited to only vaccination service, it only delivers it, not any other services) can include proper and dietary approaches, both of which can become a 'compulsory' policy, thus we can have an increase in the number of healthy babies in Turkey (babies who can be followed during their development and growth). Unfortunately, many parents are limited to the knowledge that they can acquire through today's most popular mass communication tools which was invented in a small town of England in

\footnotetext{
1 Assist. Prof., Istanbul University, Faculty of Sports Sciences, evrenkaraman@,hotmail.com
} 
1923. It should not be forgotten that the societies which have managed to establish a proper consciousness and awareness concerning nutrition and physical activity adopt functional approaches that can meet the needs of various aspects of their community (e.g. the needs of individuals coming from different age groups, socio-economic status etc.) rather than simply looking for medical treatments. Such countries promote healthy activity habits which encourage lifelong participation in physical activity and sports. In addition to physical activity, that children have a proper diet is crucial for their physical and mental development. As Hippocrates stressed in his words: "A healthy life required an individual to be informed about his own body's structure (genetic) and the effects of various foods, yet diet is never enough for a healthy life on its own, individuals should exercise too." These two components are inseparable. It is necessary to learn about the principals of a healthy diet which is very important for children's development. No matter what the age of the individual, what he eats is quite important for both physical and mental development. Regarding babyhood, both breast milk and formula milk are vitally important in a baby's life. Breast milk is the most ideal and unique nutrition not only for a baby's physical development but also for its mental development (American Academy of Pediatrics, 1997). A sixmonth breast-fed infant who can sit with or without support, can lift its head comfortably, can swallow solid foods and who possesses developed hand, mouth and eye coordination, needs complementary food so as to meet specific minerals such as primarily zinc and iron (WHO, 2009; Fewtrell et al., 2011; Scientific Advisory Committee on Nutrition and Committee on Toxicity, 2011; WHO, 2003; Gökçay, 2006; Hutton \& Hassan, 2007; Hausner et al., 2010; Griffiths et al., 2009; Gökçay et al., 2003; Gökçay et al., 2008; Kramer et al., 2003; Geneva, 2001; Simard et al., 2005; Agostoni et al., 2008). Since the moment an infant starts walking, its feeding habits might change. As activity increases its energy consumption rises. Foods are of great significance in terms of replacing spent energy (Black, 2003). If spent energy is not replaced it increases the possibility of specific illnesses such as upper respiratory tract infection. Before adolescence, the minimum nutrition and energy/calorie needs of boys and girls are generally similar. However, during adolescence, the energy needs vary depending on specific variables such as age, physical activity, growth rate etc.

Table 1. Energy Needs Based on Age Groups (Kcal/day) (Hoch et al., 2008)

\begin{tabular}{ccc}
\hline Age & Daily Energy Needs \\
\hline $4-6$ & \multicolumn{2}{c}{1800} \\
\hline $7-10$ & Boys & Girls \\
\hline $11-14$ & 2000 & 2000 \\
\hline $15-18$ & 2500 & 2200 \\
\hline 3000 & 2200 \\
\hline
\end{tabular}

Many parents complain about that their children do not eat much. Nonetheless, it is a natural process in which parents are to provide children with healthy alternatives, thus children can take whatever they need. This fact should not be forgotten. In a daily diet of a preschooler, 2-3 portions of dairy products should exist. One cup of milk, 1 cup of yogurt, $1 / 2$ cup of ice-cream and sweet yogurt, $1 / 2$ bowl of pudding are among the portion samples that $5-6$ age preschoolers can consume. Hence, two glasses of milk (400-500 gr.), a piece of cheese or dry cottage cheese can meet a child's daily need. During the early years of life, meat, egg and legumes should be given in $1 / 2$ portions (e.g. an egg, one meatball or a tablespoon of legumes), and this amount can be increased as the child grows (4-6 ages). Sample 1 portion foods for 5-6 age group preschoolers include 2-3 meatballs or meat, 3-4 small chicken drumsticks, 3-4 tablespoons of cooked legumes, and 1 egg while $1 / 2$ cup of dry beans and $1 / 3$ bowl of nuts (hazelnut, peanut, walnut) can be acknowledged as half portion (1/2). For children at the age of $1-3$, daily vegetable and fruit amounts are 3/4-1 and as they grow older, it can be increased up to $1 \frac{1}{2}$ portion. Thus, $1-3$ age group children can eat 2 table spoons of vegetables, 2 small fruit and vegetable daily, and this amount can be increased as the child grows up. For instance, 2 portions of fruit and 3 portions of vegetables are sufficient for 5-6 
age group children. Sample fruit and vegetable alternative that can be accepted as 1 portion for 5-6 age group children include 1 medium size banana, orange, peach, $3 / 4$ cups of fruit juice, $1 / 2$ smashed apple, dry fruits (apricot, grapes), 15-20 dry apricots, half cup of green bean, potato, 6-7 baked small size carrots, 1 cup of leaf lettuce, half cup of peas (Işsksoluğu, 1998; Baysal, 2000; The Ministry of health \& Hacettepe University, 2004). For preschoolers, 6 portions of cereal and grain products are sufficient for daily need. Sample cereal alternatives that is accepted as 1 portion for children are 1 slice of bread, half cup of baked cereal of a half slice of cake, 4-6 crackers, 10-15 biscuits, 4-6 tablespoons of pasta or rice, half cup of baked grain. During the first years of life, the diet might contain 2-3 thin slices of bread, 1 tablespoon of (1/2) pasta and rice (Kasnakoğlu et al., 2003). The amounts of fat and sugar group foods can changed based on preschoolers' energy needs (5-6 ages). However, considering their nutritious values, it is more appropriate to meet children's daily needs in this groups from grape molasses, puddings, tahini halva etc. Since vegetable oils contain essential fat acids and fat-soluble vitamins, and they are appetizing, half of children's daily fat needs should be met with vegetable oils, and this fat should be added to meals without being burnt (Şanlier \& Ersoy, 2004).

When it comes to children, not only exercise and sports activities but also all leisure time activities at home and school that requires burning calories should be considered as physical activities. Most parents strive for contributing their preschool-aged children's physical and mental developments through planning various physical activities. This situation does not change when these children start primary education. Families generally attempt to increase the number of physical activities for their children at school. All these physical activities develop children both physically and mentally. Parents/teachers/trainers etc. who guide children throughout this process, not only contribute to children's physical development, but also ensure that they grow to be healthy individuals. Nutrition should not be ignored in this process. The programming and planning skill of teachers or trainers concerning children's physical activities, the techniques and scientific knowledge they make use of in this process are of importance. A teacher/trainer is expected to possess the ability to broaden children's physical capacities as well as being aware of the effects that his/her habits, principals, shortly his life style might have an influence on children as well. Different dietary characteristics particular to growth and development stages should be known by the role model teacher/trainer and promoting approaches should be supported. A teacher/trainer who heartily eats molasses with tahini which is rich in iron and calcium can be more influential than a mother who say things to her children like "You should eat this because you are in adolescence," etc. As long as games/activities/exercises that aim to increase physical capacity are not supported with a sufficient and balanced diet, it is impossible to attain the target. For the optimal development of a child doing physical activity, it is a must to consume macro nutrients including carbohydrates, proteins and fats, and micro nutrients including vitamins, minerals and water adequately and appropriately. A teacher/trainer who understands the importance of physical activity and nutrition during his professional education process (e.g. university degree etc.) will absolutely use his manipulation skills on child's parents. A mother who perceives carbohydrate consumption as limited to just eating pasta and bread cannot know the fact that fructose taken through eating fruit has facilitative effects on glycogen synthesis in the liver. However, the child who says that "My teacher/trainer told me to eat 1 apple a day" will have an undeniable effect on his family who is ready to make any sacrifice for their child. Teachers/trainers cannot change families dietary habits and life styles completely. Nonetheless, teachers/trainers might have opportunities to inform parents that their children do not need to take any vitamin supplements except in situations where a child has an inflammatory disease and cannot eat a sufficient amount of food. Calcium needs of children who do physical activity increases, but calcium tablets which are used regularly might result in overuse of daily calcium and kidney calculi risks. Since such vitamins can be taken through food, with a sufficient and balanced diet the imbalance can be corrected. 
Indeed, nutrition plays a central role in maintaining energy levels before, during and after physical activity. The health and sports performance of a child who does a sport activity or plays in the garden regularly are highly based on sufficient and balanced diet and hydration condition (Turnagöl, 2007). The body sweats during physical activity so as to prevent overheating. This sweating mechanism is of more importance in children because they are more prone to overheating than adults. Thus, regular water consumption during 24 hours before the physical activity is recommended. In this sense, it is suggested to consume 400-600 ml. water in 2-3 hours before the physical activity (Shirreffs et al., 2004; Latzka \& Montain, 1999; Reimers \& Ruud, 2000; Casa, 1999). The way to have an idea about children's water consumption is to observe their urine's color. Light yellow indicates adequate consumption of water while yellow or dark yellow indicates a low level of hydration (Armstrong et al., 1994). Mineral water or drinks that contain caffeine such as coffee, tea, energy drinks or sweet/salty food might result in dehydration among children. If children consume such drinks and food, they will need more water. And when exercise and activity increases, an energy gap occurs, so appetite and eating increases so as to close this gap (King et al., 2007). The meal eaten right before the physical activity is generally described as the meal in which children store the energy they need for the activity. This meal should be eaten at least 3 hours before the activity. If children feel hungry after this big meal, they can be given small snacks 1 or 2 hours before the physical activity (in order to give teh stomach time to digest the food). That the food children consume before physical activity consists of carbohydrates (e.g. fruit, grain products etc.) facilitates the body to store energy fast (Burke et al., 2001; Stevenson et al., 2005; Wallis et al., 2006; Rodriguez et al., 2009; Hulton et al., 2013; Lima-Silva et al., 2013). However, it is also suggested to stick to food with low fiber for easy digestion. The laxative effects of high fibrous foods might result in discomfort in children during physical activity. Intense fat foods and extreme protein consumptions are also not recommended for such meals. Ensuring children consume familiar and known foods prevents the risks of allergy, digestion problems etc. Trying new food should be left to other days rather than activity days. It is possible to obtain energy that can last about 1-2 hours by consuming carbohydrates, while the combination snack of carbohydrates and proteins can give an energy that can last up to 3-4 hours. The alternatives for an energizing snack for children are listed below:

1 table spoon of peanut butter, 3-4 oat/rye cookie

$1 / 4-1 / 2$ bowl of oatmeal cooked with water or milk

2-4 table spoons of mashed chickpeas, semi-grain bread

small sandwich with tuna, egg or low-fat meat

1 or 2 eggs, 1 slice of toasted bread

Food and drink consumption of a child during physical activity can change based on the type of the physical activity and ambient temperature. It is ideal to consume 125-300 ml. liquid every 15-20 minutes. If the activity takes place in summer or winter, the sensitivity of the trainer should be taken into consideration and observed carefully. Children should not wait until they feel thirsty to start drinking water (Reimers \& Rood, 2000). Drinks including carbohydrates-electrolyte not only prevents the decreases in blood and muscle glucose stores, but also it facilitates hydration (Eskici, 2015). Yet, such sports drinks which contain carbohydrates-electrolyte are recommended to be consumed during physical activities that last more than one hour. If children's physical activity is in hot or humid weather conditions and longer than 1 hour, they can consume 125-300 ml sports drinks every 30 minutes during the activity. However, the ideal way is to consume a snack containing 30-60 gr. carbohydrate hourly (e.g. a handful of white chickpeas). The alternative energizing snacks children might consume during a physical activity are listed below:

1 medium size banana

1 medium size apple 
1 medium size orange

3-4 cookies with granola

After physical activity, children should be fed so as to ensure bodily restoration. Compared to the beginning of the exercise, the body loses an amount of fluid and its muscle glycogen stores decrease. The child can be weighed after exercise and whatever amount of body weight $\mathrm{s} /$ he has lost can be replenished with water (Akyol et al., 2008). If the child does exercise in a hot and wet environment, it is recommended to consume potassium rich foods (seafood, cheese, red and green pepper, nuts, peanut, walnut, celery and carrot, dried apricot, banana, date palm, fig, green bean, chick-pea etc.). That children consume carbohydrates after physical activity helps in supplying the muscle energy stores and muscle recovery process when consumed with protein. The basic goal is to ensure that children will consume carbohydrate-rich foods within 30 minutes following the end of the physical activity. The first meal following that process (the ideal timing is 2 hours after the activity) carbohydrate-protein rates should de 3/1. That is, 3 times more carbohydrates should be consumed than the amount of protein (30 gr. carbohydrates for every 10 gr. protein). After the physical activity, one of the following alternatives can be chosen.

1 bowl of yogurt with banana and strawberry

Muesli with yoghurt (a food that can be made with grain, dried fruit, milk or yoghurt)

small sandwich with tuna, egg or low-fat meat

1 a plate of whole grain pasta with tomatoes sauce or meat sauce

\section{Result}

Proper and adequate nutrition, which is vital for children's growth and development, is mostly influenced by external factors (e.g. family and friends' eating habits, third person's care/knowledge and experiences such as teachers/trainers etc.). When it comes to nutrition, that preschoolers are inherently active during this period and are guided to engage in physically more intense activities makes the case more complicated. Thus, it is a must to provide children with attractive foods so that we can replace the spent energy with proper energy source foods. Among the children who start regular physical activity, that the proper planning of exercise programs, proper timing and conditions, periodic assessments and adequate/balanced diet are quite important in that children would demonstrate optimal performance in their branches. The meals are to be planned in 3-4 hours intervals, meals are should not be skipped and eating time should be planned in accordance with physical activity programs.

\section{References}

Agostoni, C., Decsi, T., Fewtrell, M., Goulet, O., Kolacek, S., Koletzko, B., ...\& Shamir, R. (2008). Complementary feeding: a commentary by the ESPGHAN Committee on Nutrition. Journal of pediatric gastroenterology and nutrition, 46(1):99-110.

Akyol, A. G. A., Bilgiç, A. G. P., \& Ersoy, G. (2008). Fiziksel Aktivite, Beslenme ve Sağlıklı Yaşam.. American Academy of Pediatrics. (1997). Breastfeeding and use of human milk. Pediatrics, 100:1035-1039.

Armstrong, L. E., Maresh, C. M., Castellani, J. W., Bergeron, M. F., Kenefick, R. W., LaGasse, K. E., \& Riebe, D. (1994). Urinary indices of hydration status. International journal of sport nutrition, 4(3):265-279.

Baysal, A. (2000). Genel Beslenme. 10. Bask1, S.146, Hatipoğlu Yayınevi, Ankara

Black, M.M. (2003). Micronutrient deficiencies and cognitive functioning. The Journal of nutrition, 133(11):3927-3931.

Burke, L. M., Cox, G. R., Cummings, N. K., \& Desbrow, B. (2001).Guidelines for daily carbohydrate intake. Sports medicine, 31(4):267-299. 
Casa, D. J. (1999). Exercise in the heat. II. Critical concepts in rehydration, exertional heat illnesses, and maximizing athletic performance. Journal of athletic training, 34(3), 253.

Eskici, G. (2015). Nutrition in team sports Takım sporlarında beslenme. Journal of Human Sciences, 12(2):244-265.

Fewtrell, M., Wilson, D. C., Booth, I., \& Lucas, A. (2011). Six months of exclusive breast feeding: how good is the evidence?. BMJ: British medical journal, 342.

Geneva, S. (2001).The optimal duration of exclusive breastfeeding.A systematic review.Geneva WHO.

Gökçay, G. (2006). Strategies for the prevention of iron deficiency anaemia in children..

Gökçay, G., Furman, A., \& Neyzi, O. (2008). Updated growth curves for Turkish children aged 15 days to 60 months. Child: care, health and development, 34(4):454-463.

Gökçay, G., Turan, J. M., Partalci, A., \& Neyzi, O. (2003).Growth of infants during the first year of life according to feeding regimen in the first 4 months. Journal of tropical pediatrics, 49(1):6-12.

Griffiths, L. J., Smeeth, L., Hawkins, S. S., Cole, T. J., \& Dezateux, C. (2009). Effects of infant feeding practice on weight gain from birth to 3 years. Archives of disease in childhood, 94(8):577-582.

Hausner, H., Nicklaus, S., Issanchou, S., Mølgaard, C., \& Møller, P. (2009). Breastfeeding facilitates acceptance of a novel dietary flavour compound. e-SPEN, the European e-Journal of Clinical Nutrition and Metabolism, 4(5):231-238.

Hoch, A. Z., Goossen, K., \& Kretschmer, T. (2008).Nutritional requirements of the child and teenage athlete. Physical medicine and rehabilitation clinics of North America, 19(2):373398.

Hulton, A. T., Edwards, J. P., Gregson, W., ve ark. (2013): Effect of fat and cho meals on intermittentexercise in soccer players. Int JSports Med., 34:165-169.

Hutton, E. K., \& Hassan, E. S. (2007). Late vs early clamping of the umbilical cord in full-term neonates: systematic review and meta-analysis of controlled trials. Jama, 297(11):1241-1252.

Işıksoluğu, M. (1998). Çocuk Beslenmesi, Beslenme. Devlet Kitapları, 11. Bask1, İstanbul.

Kasnakoğlu, H. \& D. Ülgüray (2003). Ulusal Gıda ve Beslenme Stratejisi Çalışma Grubu Raporu. İktisadi Sektör ve Koordinasyon Genel Müdürlüğü, Devlet Planlama Teşkilatı, No: 2670, Ankara.

Kramer, M. S., Guo, T., Platt, R. W., Sevkovskaya, Z., Dzikovich, I., Collet, J. P., ...\& Mezen, I. (2003). Infant growth and health outcomes associated with 3 compared with 6 mo of exclusive breastfeeding. The American Journal of Clinical Nutrition, 78(2):291-295.

King, N. A., Hester, J., \& Gately, P. J. (2007).The effect of a medium-term activity-and diet-induced energy deficit on subjective appetite sensations in obese children. International journal of obesity, 31(2):334-339.

Latzka, W. A., \& Montain, S. J. (1999).Water and electrolyte requirements for exercise. Clinics in sports medicine, 18(3):513-524.

Lima-Silva, A. E., Pires, F. O., Bertuzzi, R., ve ark. (2013): Effects of a low- or a highcarbohydratediet on performance, energysystem contribution, and metabolic responses during supramaximal exercise. Appl Physiol Nutr Metab, 38:928-934.

Reimers, K. \& Ruud, J. (2000). "Essentials of Strength Training And Conditioning, 2 Rd, Creighton University, Omaha, Nebraska, Chapter 12, pp:246-249.

Rodriguez, N. R., Di Marco, N. M., Langley, S. (2009): American dietetic association; dietitiansof Canada; american college of sportsmedicine. American college of sports medicine position stand.Nutrition and athleticperformance. Med Sci Sports Exerc, 41(3):709-731.

Sağlık Bakanlı̆̆1 \& Hacettepe Üniversitesi (2004).Türkiye’ye Özgü Beslenme Rehberi. Ankara.

Scientific Advisory Committee on Nutrition and Committee on Toxicity. (2011). Joint Statement: Timing of Introduction of Gluten into the Infant Diet. SACN: London. 
Shirreffs, S. M., Armstrong, L. E., \& Cheuvront, S. N. (2004). Fluid and electrolyte needs for preparation and recovery from training and competition. Journal of sports sciences, 22(1):57-63.

Simard, I., O’Brien, H.T., Beaudoin, A., Turcotte, D., Damant, D., Ferland, S., ...\& Champoux, L. (2005). Factors influencing the initiation and duration of breastfeeding among low-income women followed by the Canada prenatal nutrition program in 4 regions of Quebec. Journal of human lactation, 21(3):327-337.

Stevenson E, Williams C, McComb G, ve ark. (2005): Improved recovery from prolongedexercise following the consumptionof low glycemic index carbohydrate meals. International Journal of Sport Nutrition and Exercise Metabolism, 15:333-349.

Şanlıer, N. \& Ersoy, Y. (2004).Çocuk ve Beslenme.İstanbul, Morpa Kültür Yayınları, 2. Baskı

Turnagöl, H.H. (2007). Spor Yapan Çocuğun Beslenmesi. Turkiye Klinikleri Journal of Pediatrical Sciences, 3(6):35-42.

Wallis GA, Dawson R, Achten J, ve ark. (2006): Metabolic response to carbohydrate ingestion during exercise in males and females.Am J Physiol Endocrinol Metab,290, E708-E715.

World Health Organization, \& UNICEF.(2003). Global strategy for infant and young child feeding. World Health Organization.

World Health Organization.(2009). Global strategy for infant and young child feeding. 2003. Geneva: WHO Google Scholar. 